\title{
Health indicators as indicators of the progress of civilization
}

\author{
Andrzej Boczkowski
}

Instytut Socjologii, Uniwersytet Opolski

Address for correspondence: Uniwersytet Opolski, Instytut Socjologii, Katowicka 89, 45-061 Opole, phone 7745274 80, 663375 850, aboczkowski@uni.opole.pl

\section{Abstract}

The health status of a population defined by deliberately chosen indicators can be treated as one of principal elements of the civilization progress constituted by the development of the public health area, i.e. improvement of particular indicators relating directly to the health of the population. Within different societies this process runs at different rates and has different priorities. The activities aiming at increasing its dynamics and rationalizing its targets may contribute to the civilization progress in its health dimension.

The paper is an attempt to apply a taxonomic method of international comparisons in order to set the population health development goals. The method is illustrated by the example of $28 \mathrm{EU}$ countries. The health status of the populations of these countries has been operationalized in the set of six indicators. On the basis of applying the method some procedures of setting out the development perspective within the population health area is illustrated using the example of Poland.

\section{Key words: population health, taxonomic method, development goals}

\section{Stowa kluczowe: zdrowie populacji, metoda taksonomiczna, cele rozwojowe}

Ministerstwo Nauki

i Szkolnictwa Wyższego
Przygotowanie do wydania elektronicznego finansowane w ramach umowy 641/P-DUN/2018 ze środków Ministra Nauki i Szkolnictwa Wyższego przeznaczonych na działalność upowszechniającą naukę.

\section{Civilization and health}

It is generally accepted that the different properties of particular areas of social life to a large extent determine the phenomena and processes forming the health condition of the population. Therefore, it can be assumed that health indicators in a specific way show the general situation of society, which can be defined as the level of civilization development, civilization advancement or civilization progress.

The concept of civilization can be used attributively (to indicate a characteristic or set of characteristics of an individual or society), processually (as a path of, or the process of acquiring characteristics or properties that form subsequent stages of civilization) or as a certain entity (to indicate a macro-social group).
Clear traces of these semantic distinctions can be found in social sciences and in historical literature, where the term 'civilization' is used in a variety of ways. In one of the meanings, used and developed above all in Germany from the late nineteenth century to World War II, and perhaps best represented in the works of Alfred Weber, and in the English-speaking world by Robert M. MacIver, the term 'civilization' - in contrast to 'society' and especially 'culture' - covers primarily material, technological and to some extent organizational aspects of social life, excluding the deeper, more 'spiritual', cultural or aesthetic dimensions.

Another meaning of the term, adopted by Norbert Elias in On the Process of Civilization, focused on the 'socializing' process in the course of which the image of a civilized person construed at the European courts 
and early-bourgeois environments, was disseminated and institutionalized [1]. This concept of civilization, or rather implanting civilization, was connected with an earlier definition of civilization going back to the French Enlightenment, in which it was contrasted with barbarism, and in more detailed approaches it was presented as a process of exercising increasing control and regulation of the forces of nature (in their various manifestations) in order to better meet the needs of and more effectively implement the interests of man, society and humankind.

Researchers using the term 'civilization' in the third, and probably the most widespread understanding, despite the sometimes significant differences in research perspectives, concepts and methodologies, used this term to define isolated socio-cultural entities having in common some very important characteristics, primarily of cultural nature. That is how the civilization was understood by Max Weber, Emile Durkheim, Oswald Spengler, Pitirim Sorokin, Arnold Toynbee, Alfred L. Kroeber, Fernand Braudel, and more recently Immanuel Wallerstein and Samuel Huntington. In a similar sense, the term is used by Shmuel Eisenstadt, for whom civilization is a "combination of ontological or cosmological visions, of conceptions of trans-mundane and mundane reality, with the definition, construction, and regulation of the major arenas of social life and interaction" [2].

The core of every civilization is the mutual relationship between the formulation, dissemination, articulation and constant reinterpretation of basic ontological visions that dominate in a given society, its basic ideological assumptions and central symbols on the one hand, and the definition and regulation of the institutional sphere on the other. The organization, dynamics and validation of particular areas of this sphere are shaped within the framework set by such definitions and regulations.

The impact of ontological visions and premises on institutional areas is achieved through the processes of interaction and control that are developed in society. Control processes are not restricted to enforcing power in the narrow, political sense. To a large extent, they are triggered by the elites of a given society - political, cultural and economic, and those that construct a space of solidarity and collective imaginations of the leading social groups, representing various cultural options and interests.

The structure of such elites is closely related to the basic cultural orientations prevailing in society. Different types of elites represent different orientations or visions and seek to enforce different ways of control over the allocation of basic resources.

Such a combination of ontological visions and the shaping of institutional forms and collective identities is always closely connected with the organizational aspects of each institutional system, including the sphere of health, to which the approaches described above can be referred in particular.

The health status of the population determined by a set or sets of health indicators can be treated as a fundamental (leading, dominant) element of civilization progress for two reasons. First of all, all the components of the civilization process - regardless of the theoretical and conceptual framework serving the recognition of this process - undoubtedly have a certain impact, generally positive or negative, on the health status of the population. Second of all, only improving health, including maintaining health, etc (both in a population and individual approach) fully corresponds to the contemporary understanding of progress as a development recognized as positive by all conscious members of society (see [3]).

It can be said that civilization progress understood as regulating nature for the good of man (society), in particular for a better functioning of both these entities, is done by imposing rational constraints onto individual areas of natural (uncontrolled) functioning. The result, or rather results/effects in subsequent stages of the existence of society are the changes in all parameters of its functioning. The structure and dynamics of these changes show that some of the 'natural' elements undergo rationalization or 'civilizing' more easily, while other are more resistant to them, and so 'implanting civilization' may be stopped or revoked.

In the health context, civilization progress is the development of the public health sphere, leading to the improvement of different health indicators. This is achieved by imposing ever-greater restrictions on health threats, conditions conducive to disease, increasing the risk of disease, premature death, etc. This process takes place in different societies at different rates and taking into account different priorities. Activities aimed at increasing its dynamics and rationalization of objectives, undertaken by the World Health Organization (in particular in the strategy of Health for All by the Year $2000 \ldots$ and beyond) contribute only to a limited extent to the progress of civilization in the health dimension. This does not mean, of course, that we should renounce the aspirations to design or even plan such activities, but perhaps apply more effective approaches and more accurate set of instruments.

\section{Two ways of setting development goals}

Any design or plan, also in the field of public health, must start with setting goals that you would like to achieve in the future. ${ }^{1}$ There are usually two main approaches to doing that.

The first involves extrapolating trends that occurred in the past. This procedure assumes a specific recording of the past, without taking into account the irregular dynamics of growth and qualitative turning points of development, especially technological, that is why this approach is often criticized. It requires very detailed statistical data showing long stretches of time, and moreover, it can be used only in such spheres or solutions (in particular in the field of public health) that already exist in a given society. This procedure will not apply when it comes to initiating previously non-existent solutions.

The second approach is based on international comparisons. It can be assumed that it is an expression of the aspirations of a given country (society), ${ }^{2}$ and the motives that underlie opting for more or less ambitious goals are 
conditioned by either overt or covert political and ideological competition between the countries. This approach is underpinned by the idea of one-way development of a given sphere of reality. It is understood that while developing, countries cannot skip certain unavoidable intermediate stages. The problem then is to determine which countries are situated above the one that sets development goals for itself, and what is their distance from it. The level of development in these countries would be the reference point when determining the order of magnitude for the proposed or planned objectives, while the conditions that were necessary to achieve the objectives in the higherranking countries can provide information on the conditions that should be created to achieve the planned goals.

If the setting of objectives were to be carried out in relation to each variable that comprised the ultimate objective, formulated in more general terms, the procedure would be simple. In order to determine the position of a given country in relation to other countries, for instance in terms of premature mortality due to specific diseases, it would be enough to rank the countries and calculate the differences in the number of deaths per 100,000 inhabitants. The country occupying the closest better position in the ranking would be the nearest more developed neighbour due to this single variable.

The problem, however, is that the development of the public health sphere (the progress of civilization in its health dimension) is a highly complex process and its components, usually correlated, form a specific system. Also, it is not uncommon that a relatively worse position of one component (for example the above-mentioned mortality due to specific diseases) is observed alongside a relatively better position of another component (for example deaths due to external causes).

\section{Applying the taxonomic method}

It follows that a synthesizing method should be used in the search for countries whose civilization progress in the dimension of population health status could provide developmental goals for a given country. The distances between countries constituting measures of resemblance, should be synthetic, and therefore based on many variables. Further, a description of such a method proposed several decades ago by Zygmunt Gostkowski [5] $]^{3}$ and Zdzisław Hellwig [6], will be presented. This method was originally used to construct the typology of any entities that can be characterized using several variables, which is why it was called the taxonomic method [7]. In this article it will be discussed using the example of $28 \mathrm{EU}$ countries. The health condition of the population of these countries - which as it was stipulated in the introduction to this article - can be treated as being indicative for the progress of civilization, was operationalized using six variables (indicators) selected from the set used in the recently published study of the European office of the World Health Organization [8]. The choice was made according to the criterion of negative aspects of the health status. Specifically, in order to take into account the significant life expectancy at birth ratio, a change was introduced to the analysis, namely the opposite ratio was introduced, i.e. expected years of life lost at birth, with an optimal number of 100 years of life. ${ }^{4}$ Indicators for individual countries (the latest available in the statistical databases of WHO accessed while preparing the above-mentioned report) are presented in Table I. An assumption has been adopted that these indicators accurately represent the health status of the population resulting from the functioning of the health sphere of social life, which was institutionalized during the process of forming the civilization of European societies.

Due to the different units of measurement, it is necessary to standardize the values of individual variables. For this purpose, both Hellwig and Gostkowski recommend using the following formula:

$$
\frac{X_{j}-\bar{x}}{s_{j}} \quad j=1,2, \ldots N
$$

where each value of each variable expressed in its relevant units of measurement takes on the standardized form as a result of dividing the difference of a given value and the average for a given variable by the standard deviation for this variable.

The 28 EU countries characterized by six variables are located conceptually in the six-dimensional Euclidean space, and so using the following formula:

$$
c_{i j}=\left|\sum_{k=1}^{m}\left(x_{i k}-x_{j k}\right)^{2}\right|^{0,5} \quad i, j=1,2, \ldots N
$$

the distances between any country and all other countries can be calculated. As follows from the formula above, the distance $c$ between the country $\boldsymbol{i}$ and the country $\boldsymbol{j}$ equals the square root of the sum of squared differences for each of the $\boldsymbol{m}$ variables $(\boldsymbol{m}=6)$. The established distance is a cumulative measure: it is the mathematical expression of all distances because of each of the 6 dimensions according to which EU countries are to be compared. The results of these calculations can be presented in a symmetrical matrix of distances, as shown in Table II. This matrix allows obtaining an objective typology of 28 countries based on six variables. For this purpose, a simple graph method can be used to divide the set of all countries into close-knit typological groups [6]. This method consists in establishing the so-called shortest graph - one where each country is connected to its nearest neighbour, i.e. its model of similarity. For each country, you can find such a model by finding in the corresponding row of the matrix the smallest number expressing the shortest distance to another country. This is shown by the last two columns in Table II.

The location of the country in its typological group constituting an important reference system significantly helps in the assessment and selection of development goals. In Figure 1 the shortest similarity graph for the analyzed set of countries is presented and the typological groups differentiated by it are shown.

Each of the 28 countries is shown in the figure as a point, and each pair of points is connected with an arrow directed towards the country that is the closest model of similarity. Some points are connected by two arrows 


\begin{tabular}{|c|c|c|c|c|c|c|}
\hline Country & $\begin{array}{c}\text { Premature (30-70 } \\
\text { years) deaths from } \\
\text { cardiovascular dise- } \\
\text { ases, cancer, diabetes, } \\
\text { chronic respiratory } \\
\text { diseases - per 100,000 } \\
\text { population }\end{array}$ & $\begin{array}{c}\text { Deaths from external } \\
\text { causes (injuries, po- } \\
\text { isoning) - per 100,000 } \\
\text { population }\end{array}$ & $\begin{array}{c}\text { Infant morta- } \\
\text { lity - deaths } \\
\text { per } 1,000 \text { live } \\
\text { births }\end{array}$ & $\begin{array}{c}\% \text { of adults } \\
\text { regularly } \\
\text { smoking } \\
\text { tobacco }\end{array}$ & $\begin{array}{c}\% \text { obese } \\
\text { adults } \\
(\mathrm{BMI} \geq 30)\end{array}$ & $\begin{array}{c}\text { Expected } \\
\text { years of life } \\
\text { lost } \\
\text { at birth }\end{array}$ \\
\hline Austria & 247.6 & 36.9 & 3.6 & 28.9 & 18.4 & 18.7 \\
\hline Belgium & 264.4 & 47.3 & 3.6 & 26.1 & 20.2 & 19.7 \\
\hline Bulgaria & 563.1 & 32.7 & 7.8 & 37.9 & 23.2 & 25.7 \\
\hline Croatia & 401.0 & 52.0 & 3.6 & 34.5 & 23.3 & 22.6 \\
\hline Cyprus & 201.5 & 28.1 & 2.8 & 28.9 & 23.8 & 18.0 \\
\hline Czech Republic & 364.0 & 45.7 & 2.6 & 32.3 & 26.8 & 21.8 \\
\hline Denmark & 260.9 & 30.5 & 3.4 & 20.7 & 19.3 & 19.9 \\
\hline Estonia & 414.9 & 77.2 & 2.4 & 33.6 & 22.6 & 23.4 \\
\hline Finland & 239.6 & 57.3 & 2.4 & 22.4 & 20.6 & 19.2 \\
\hline France & 237.6 & 43.2 & 3.5 & 30.3 & 23.9 & 18.0 \\
\hline Greece & 230.1 & 26.3 & 3.4 & 45.1 & 22.9 & 19.1 \\
\hline Spain & 221.2 & 22.6 & 3.2 & 31.0 & 23.7 & 17.5 \\
\hline The Netherlands & 248.8 & 26.3 & 3.6 & 29.0 & 19.8 & 18.5 \\
\hline Ireland & 252.8 & 36.2 & 3.8 & 23.2 & 25.6 & 19.2 \\
\hline Lithuania & 524.6 & 113.1 & 4.3 & 30.1 & 25.9 & 26.4 \\
\hline Luxembourg & 227.2 & 40.4 & 2.8 & 28.9 & 23.1 & 18.3 \\
\hline Latvia & 563.1 & 82.0 & 6.3 & 35.3 & 23.7 & 25.9 \\
\hline Malta & 260.0 & 19.5 & 6.3 & 26.6 & 26.6 & 19.0 \\
\hline Germany & 258.5 & 26.9 & 3.3 & 32.9 & 20.1 & 18.9 \\
\hline Poland & 427.7 & 54.9 & 4.7 & 30.1 & 25.2 & 23.0 \\
\hline Portugal & 235.6 & 29.2 & 3.1 & 22.4 & 20.1 & 19.3 \\
\hline Romania & 501.0 & 53.3 & 9.4 & 31.7 & 21.7 & 26.2 \\
\hline Slovakia & 457.1 & 50.1 & 5.7 & 28.1 & 25.7 & 24.3 \\
\hline Slovenia & 289.0 & 56.3 & 2.5 & 21.3 & 25.1 & 20.0 \\
\hline Sweden & 200.4 & 35.4 & 2.5 & 22.5 & 20.5 & 18.2 \\
\hline Hungary & 562.7 & 52.2 & 4.9 & 30.8 & 24.0 & 24.7 \\
\hline Great Britain & 264.2 & 26.3 & 4.3 & 21.1 & 28.1 & 19.2 \\
\hline Italy & 222.0 & 25.3 & 3.4 & 24.0 & 21.0 & 17.5 \\
\hline Average & 326.5 & 43.8 & 4.04 & 28.92 & 23.03 & 20.79 \\
\hline $\begin{array}{l}\text { Standard } \\
\text { deviation }\end{array}$ & 124.1 & 20.8 & 1.69 & 5.67 & 2.56 & 2.96 \\
\hline
\end{tabular}

Table I. Selected indicators of the health status of EU populations (according to data of the World Health Organization in the period of 2010-2014).

Source: Own elaboration based on The European Health Report 2015. Targets and beyond - reaching new frontiers in evidence, WHO Regional Office for Europe, Copenhagen 2015, p. 119-125 [8].

pointing in opposite directions - this means that these two countries are models of similarity for one another. There are seven typological groups in the graph presented in Figure 1. The distinction of each of them consists in the fact that they include countries connected by a shorter or longer chain of similarities; however, none of them is connected by the closest similarity with a country from another typological group (obviously, more distant similarities - somehow secondary - do occur and are marked in the graph with a dotted line). It can be said that typological groups form some kind of civilization niche - of course within the scope defined operationally by the variables included in the analysis.

A country constituting a model of similarity for another country does not have to be a more advanced civilization (in the limited scope presented here); in fact, it can be a less advanced country. However, looking for potential developmental patterns or positive areas to which one could relate their aspirations and development opportunities, one should be interested primarily in those 


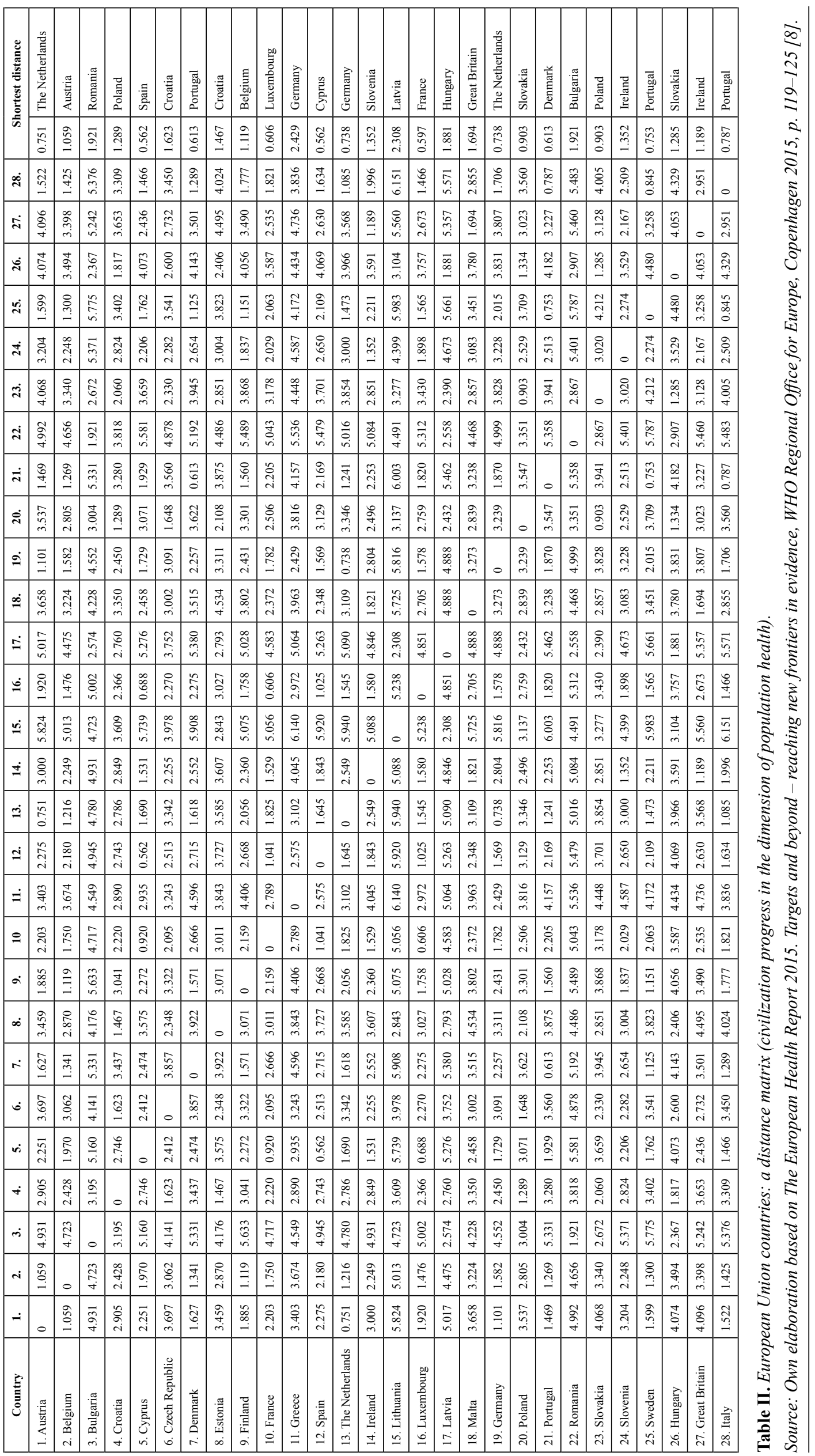




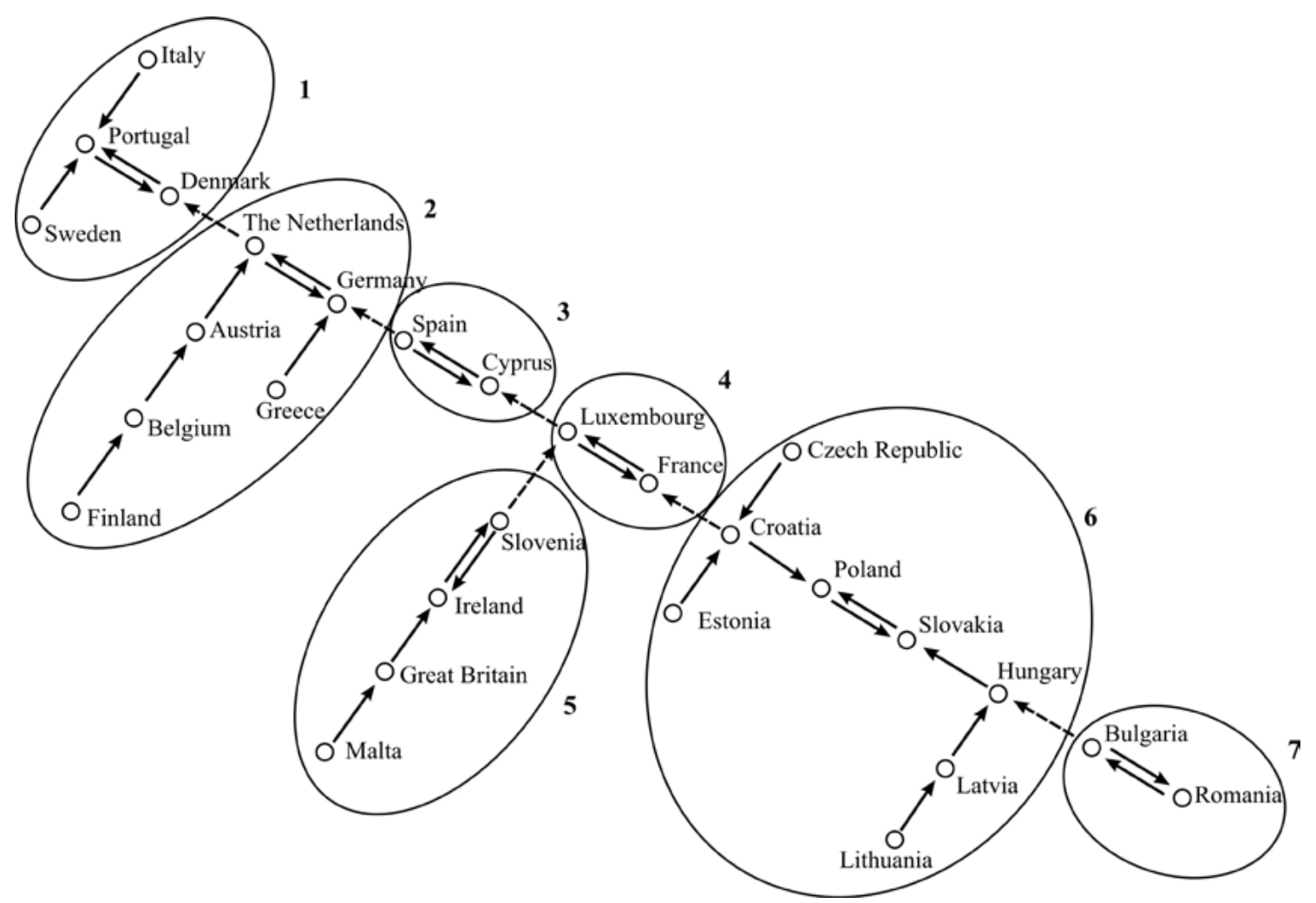

Figure 1. The shortest graph of similarities between EU countries (according to the criterion of civilization progress in terms of population health status).

Source: Own work.

countries that are ranked higher on a scale of development. Z. Gostkowski described a simple method of constructing such a scale to measure developmental levels using a similarity distance matrix [5]. It can be used in the analysis attempted here.

The assumption is that one country has achieved the best $^{5}$ values of indicators for all variables included in the analysis. The parameters of such an 'ideal' or model country, together with an indication of the countries to which they refer, are shown in Table III.

Further, the ideal or model country (which is in fact a certain thought construct) is situated in the six-dimensional Euclidean space, and using the formula (2), the distance between each country and this mental construct is calculated. Such distances can be defined as development distances, since their numerical values express the level of development achieved by each country (in the area defined by the set of variables adopted in the analysis). The shorter the development distance, the higher the level of civilization development (progress) in the health aspect. The ranking of countries according to these distances is culminated with the construction of a specific measuring scale - 'development ladder', presented in Figure 2.

\section{Methods of setting development goals}

Using the results of the application of both procedures, a specific development perspective (model of civilization progress) in the area of population health can be found for each country, specifically for Poland, i.e. a group of variable values included in the analysis that could constitute a set of relatively realistic planning goals. It could be done in various ways, illustrated using the example of Poland.

The first of these methods involves using average values, treated as an expression of the main development tendency within the EU countries. For all countries ranked higher than Poland on the 'development ladder' (Figure 2), the average value for each of the component variables is calculated as shown in Table IV. These averages can be taken as development goals. ${ }^{6}$

The proposed approach takes into account the issue of development irregularities between countries in terms of individual variables. Thanks to using average values that express the general development tendency, the suggested goals somehow already contain corrections due to irregularities (dispersion) in the relations between variables. Of course, it may happen that among the countries ranked higher on the development ladder than a given country, there will be countries whose values of some variables will be particularly distant from the values of these variables for a given country - i.e. particularly dis- 


\begin{tabular}{|c|c|c|c|c|c|c|}
\hline \multirow[t]{3}{*}{ Model country } & $\begin{array}{l}\text { Premature (30-70 years) } \\
\text { deaths from cardiovascular } \\
\text { diseases, cancer, diabetes, } \\
\text { chronic respiratory diseases } \\
\text { - per } 100,000 \text { population }\end{array}$ & $\begin{array}{l}\text { Deaths from exter- } \\
\text { nal causes (inju- } \\
\text { ries, poisoning) } \\
\text { - per } 100,000 \\
\text { population }\end{array}$ & $\begin{array}{l}\text { Infant morta- } \\
\text { lity - deaths } \\
\text { per } 1,000 \text { live } \\
\text { births }\end{array}$ & $\begin{array}{l}\text { \% of adults } \\
\text { regularly } \\
\text { smoking } \\
\text { tobacco }\end{array}$ & 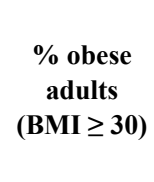 & $\begin{array}{c}\text { Expected } \\
\text { years of life } \\
\text { lost at birth }\end{array}$ \\
\hline & 200 & 19.5 & 2.4 & 21.1 & 18.4 & 17.5 \\
\hline & Sweden & Malta & $\begin{array}{l}\text { Estonia, } \\
\text { Finland }\end{array}$ & Great Britain & Austria & $\begin{array}{l}\text { The Nether- } \\
\text { lands, Italy }\end{array}$ \\
\hline
\end{tabular}

Table III. Parameters of the population health status for the model country.

Source: Own elaboration.

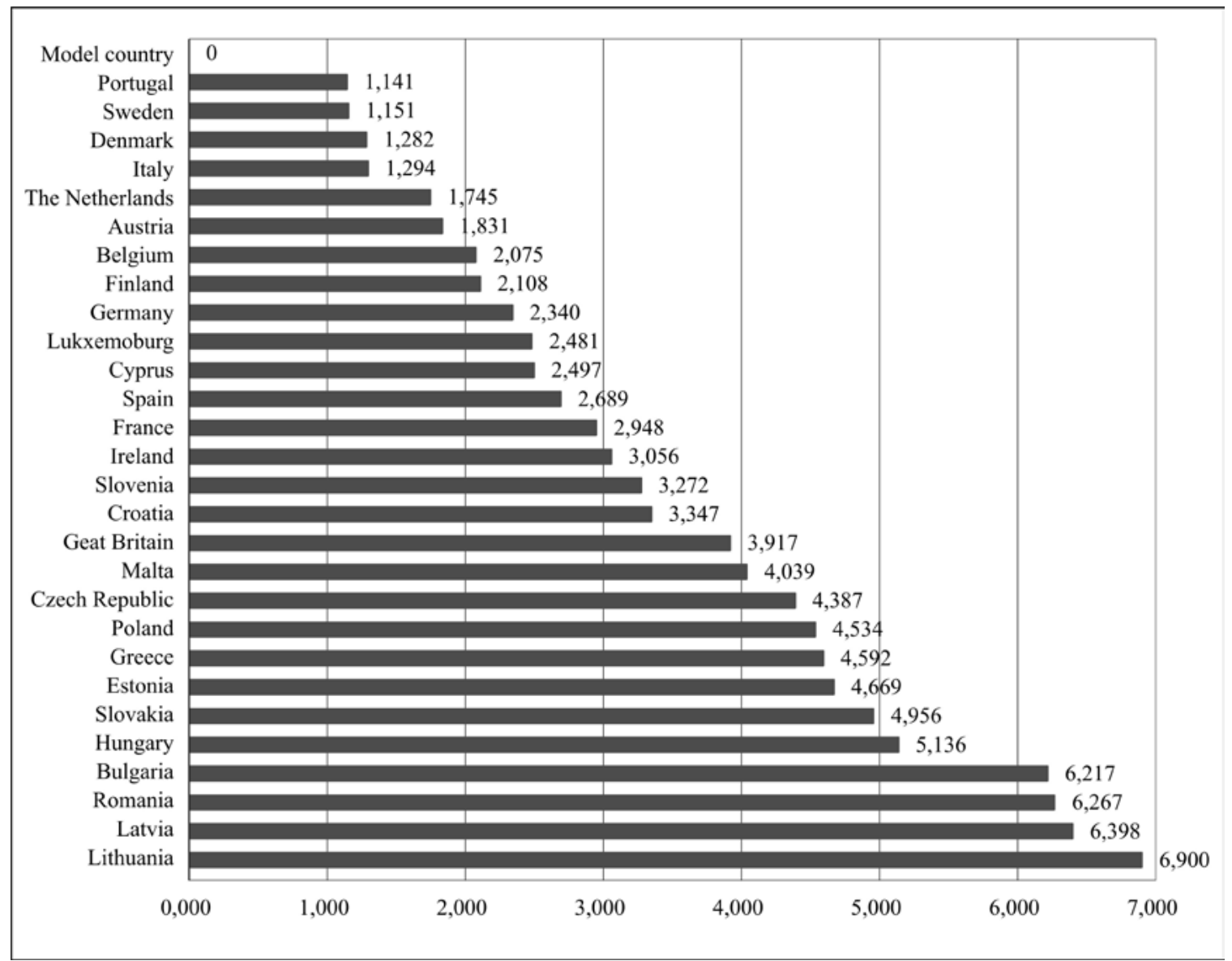

Figure 2. EU countries: distances in civilization progress in the population health dimension (in relation to the model country).

Source: Own work.

tinct from it. These countries should not be included in the calculations. As a kind of criterion of separateness and exclusion, Z. Gostkowski proposes to use the average rate of all distances of similarity between the studied countries plus their double standard deviation. Countries better developed from a given country, and whose distances from it are greater than this rate (which can be defined as a critical or threshold distance), should be excluded from the calculations [5].

In the case analyzed here, the critical distance is 5.974. Since Poland's distances to countries higher up on the development ladder are within the range of 1.289 to 3.709 , there is no need for such exclusion.
The second method of defining the developmental perspective (model of civilization progress) in the area of population health is to choose a specific country that could serve as a model or developmental standard by providing the desired goals. Such a country must meet all of the following conditions: (1) it should be located higher on the development ladder, (2) the values characterizing all variables should be better than the values for the country for which developmental goals are sought, (3) it should be the country closest in terms of the similarity distance [5]. Using this method in the analysis conducted here brings the result presented in the middle part of Table V. 


\begin{tabular}{|l|c|c|c|c|c|c|}
\hline \multirow{2}{*}{ Poland } & $\begin{array}{c}\text { Premature (30-70 years) } \\
\text { deaths from cardiova- } \\
\text { scular diseases, cancer, } \\
\text { diabetes, chronic respira- } \\
\text { tory diseases - per 100,000 } \\
\text { population }\end{array}$ & $\begin{array}{c}\text { Deaths from } \\
\text { external causes } \\
\text { (injuries, po- } \\
\text { isoning) - per } \\
\mathbf{1 0 0 , 0 0 0} \text { popula- } \\
\text { tion }\end{array}$ & $\begin{array}{c}\text { Infant morta- } \\
\text { lity - deaths } \\
\text { per 1,000 live } \\
\text { births }\end{array}$ & $\begin{array}{c}\text { \% of adults } \\
\text { regularly } \\
\text { smoking } \\
\text { tobacco }\end{array}$ & $\begin{array}{c}\text { \% obese } \\
\text { adults } \\
\text { (BMI } \geq \mathbf{3 0} \text { ) }\end{array}$ & $\begin{array}{c}\text { Expected } \\
\text { years of life } \\
\text { lost at birth }\end{array}$ \\
\hline Current state & 428 & 54.9 & 4.7 & 30.1 & 25.2 & 23 \\
\hline Development goals & 264 & 35.6 & 3.2 & 24.9 & 22 & 19.1 \\
\hline
\end{tabular}

Table IV. Potential development goals for Poland in the field of population health - the first method of setting goals. Source: Own elaboration.

\begin{tabular}{|c|c|c|c|c|c|c|c|}
\hline \multicolumn{2}{|c|}{ Countries } & 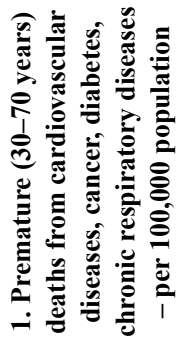 & 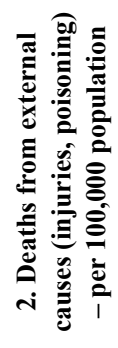 & 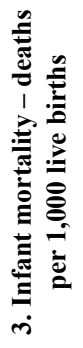 & 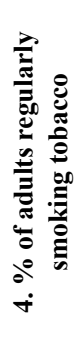 & 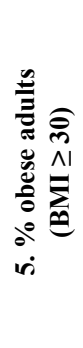 & 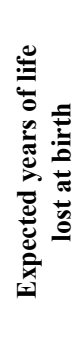 \\
\hline \multicolumn{2}{|c|}{ Poland (current state) } & 428 & 54.9 & 4.7 & 30.1 & 25.2 & 23 \\
\hline \multirow{5}{*}{ 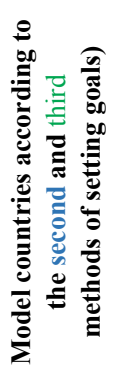 } & Cyprus & 202 & 28.1 & 2.8 & 28.9 & 23.8 & 18 \\
\hline & Luxembourg & 227 & 40.4 & 2.8 & 28.9 & 23.1 & 18.3 \\
\hline & Czech Republic & 364 & 45.7 & 2.6 & & & 21.8 \\
\hline & Croatia & & & & & 23.3 & \\
\hline & Slovakia & & & & 28.1 & & \\
\hline
\end{tabular}

Table V. Potential development goals for Poland in the field of population health - the second and third methods of setting goals. Source: Own elaboration.

Among the countries located higher than Poland on the ladder of development of the population health sphere are Cyprus, and right behind it, Luxembourg, which are relatively the closest countries meeting the conditions (1) and (2). This result is not realistic in terms of application possibilities, especially in terms of improving indicators 1, 2 and 6. Moreover, due to the above-described procedures for the application of taxonomic measures and their results, especially doubtful is the question of possible (even if only hypothetical) determination as the benchmark for Poland a country outside its typological group. And yet, as can be seen in Figure 1, the separateness or specificity of particular typological groups are not limited to connections in the form of mathematically calculated shortest distances of similarity, but lie also in the parallel or similarity of functioning of many spheres of social life in the countries belonging to a given group.

Therefore, it is possible to propose a third way of determining developmental goals in the area of population health. This method constitutes only a modification of the second method, yet an important one, consisting in a change in the conditions that the developmental pattern for the health sphere of a given country should correspond with: (1) developmental patterns for individual variables do not have to come from one country, (2) the model country or countries may be situated higher or lower on the development ladder, (3) the values of all variables should be better than the values for the country for which developmental goals are sought, (4) it should be the closest country in terms of distance of similarity (having satisfied conditions 2 and 3 ).

The results of applying this method (and fulfilling all four conditions) are shown in the lower part of Table V. The developmental pattern for Poland presented in it contains the closest better variables from three countries belonging to the same typological group as Poland.

Similarly, other - perhaps more ambitious development goals - can be determined for the health sphere of the population, or another, more advanced civilization development pattern can be sought. The goals of those 
further established developmental patterns would be increasingly higher (sometimes much higher) than the goals obtained from the first model. They could be treated as long-term goals, and goals obtained from the first model - as direct tasks to be accomplished in a shorter period. It is not difficult to notice that subsequent developmental patterns would create a specific development trajectory leading in its longest perspective to the 'ideal country', i.e. a set of the highest achievements in the sphere of population health in the entire group of countries compared in this respect. Each subsequent developmental standard pattern (model) would represent a higher level of development in relation to all the variables included.

By sorting the countries according to subsequent developmental levels, the process of civilization development is being reconstructed to a certain extent. This reconstruction is of course artificial - diachronic relations are replaced by synchronous relations [5]. However, it is worth considering whether it would be possible to indicate in the existing development of a civilizationally more advanced country, a moment or period that could be treated as the most appropriate for the current development level of the country setting its development goals. Which of the more developed countries (in the scope analyzed here) at the moment or period of its history was the most similar to the country now setting development goals?

\section{Final remarks}

The method presented here could help answer these questions. Instead of analyzing each of the $N$ different countries at a particular moment, it would be possible to analyze each of the $N$ countries at different times or periods by treating these moments / periods as separate entities (different versions of countries) and placing them in an $m$-dimensional space, and then using the procedures described above. It is obvious that this method is only a formal mental tool and does not concern important theoretical problems related to the introduction of a historical perspective in seeking developmental goals. It seems that a fundamental problem remains unresolved (unsolvable?) - to what extent the future civilization development of a given country can be a repetition of the history of another country?

The method described in this article and tested using examples is only a relatively systematic way of comparing countries in terms of several variables. All decisions as to which set of developmental goals in the sphere of population health, or more broadly in the area of public health, should be chosen as a result of these and similar comparisons, cannot and should not be taken mechanically, especially using only one of the possible procedures. The ones that have been described above are to a large extent dependent on the selection and credibility of the statistical material used and on the assessing criteria of potential users and beneficiaries of this method. In any case, the optimal solution would be to establish development goals in several variations, which should then be analyzed in the context of a wider knowledge of the countries involved and the variables.

\section{Notes}

1 The general and specific objectives of world health policy were established when the Health for All 2000 strategy was launched, and then also in the dimension of the world regions and for individual Member States (see [4]).

2 To facilitate understanding, and due to the methodology adopted, thereinafter there will be mention of countries.

${ }^{3}$ The structure and main ideas of this work have been used in this article.

${ }^{4}$ A similar assumption is made in the case of HALE (Health Adjustment Life Expectancy) and DALY (Disability Adjusted Life Years) indicators.

5 The terms 'better - worse' allow to bypass some of the language traps connected with the fact that all indicators included in the analysis are in fact negative - the smaller the values of variables, the greater the progress of civilization in terms of health.

${ }^{6}$ This procedure can be used primarily for countries located lower on the development ladder. For a country located at the top of this ladder, the goals could possibly be obtained from the model country - with the exception of those variables whose maximum values come from the country for which the objectives are sought, of course.

\section{References}

1. Elias N., O procesie cywilizacji. Analizy socjo- $i$ psychogenetyczne, Wydawnictwo W.A.B., Warszawa 2011.

2. Eisenstadt S.N., Civilizations, in: Smelser N.J., Bates P.B. (eds.), Encyclopedia of the Social \& Behavioral Sciences, Elsevier, USA, 2001: 1916.

3. Sztompka P., Socjologia zmian społecznych, Wydawnictwo Znak, Kraków 2005.

4. Targets for health for all. Targets in support of the European regional strategy for health for all, WHO Regional Office for Europe, Copenhagen 1985.

5. Gostkowski Z., Zastosowanie miar taksonomicznych $w$ ustalaniu docelowych zadań planowania w oparciu o porównania międzynarodowe, "Studia Socjologiczne" 1971; 2 (41): 55-64.

6. Hellwig Z., Procedure of Evaluating High-Level Manpower Data and Typology of Countries by Means of the Taxonomic Method, in: Gostkowski Z. (ed.), Towards a System of Human Resources Indicators for Less Developed Countries, Ossolineum, Wrocław 1972: 115-137.

7. Florek K., Łukaszewicz J., Perkal J., Steinhaus H., Zubrzycki S., Taksonomia wrocławska, "Przegląd Antropologiczny" 1951; 17: 193-211.

8. The European Health Report 2015. Targets and beyondreaching new frontiers in evidence, WHO Regional Office for Europe, Copenhagen 2015. 